\title{
Museums and museologies in Norway
}

\author{
Brita BrenNa
}

\begin{abstract}
The Norwegian museum landscape has been refurbished during the last decades. Smaller and topographically scattered units have been merged into large museum conglomerates, small streams of funding have become regular rivers of governmental financial support, and the notion of the societal role has become the landmark for all museums to navigate by. Museological research and education has grown from being a wild flower to become a modest perennial in the museum field. This article will from such a modest museological perspective outline some of the basic features of the changes museums and museology has gone through. The particular perspective from which the author views the field is the MA-programme in museology at the University of Oslo.
\end{abstract}

Keywords: Norwegian museums, museology, heritage studies, Norway, museum history.

In 1975 the number of museums that received state support in Norway were 179, in 1995, 700, in 2006, 188 and in 2016, 109. These fluctuating numbers will in this article be a frame within which to paint the Norwegian museum landscape and the events that have changed it during the last decades. As the numbers show, there have been large structural changes, and the features of the landscape from 1975 are hardly recognizable today. The Norwegian heritage sector is financially dependent on state subsidies, and the fluctuations above are indications of to what degree governmental decisions influence the museum sector. However, most museums are foundations or companies limited by shares, they are most often owned by nonprofit private associations, whilst around $3 / 4$ of the operational costs come from government funding. Not all changes come from above, but museum and heritage policies are important for understanding this complex organism, the museum sector. On the other hand, these changes have only to a limited degree be discernible for the regular museum visitor, as most of the public arenas of the museums have been left intact, and there has been very few museum shut downs. This article will far from cover all changes, but will present what I deem the most important ones, before discussing how museum education and museology have changed during these years.

\section{A WILD AND FLOWERING MUSEUM FIELD}

If you find my words in the opening paragraph overtly metaphorical, my excuse is that these 

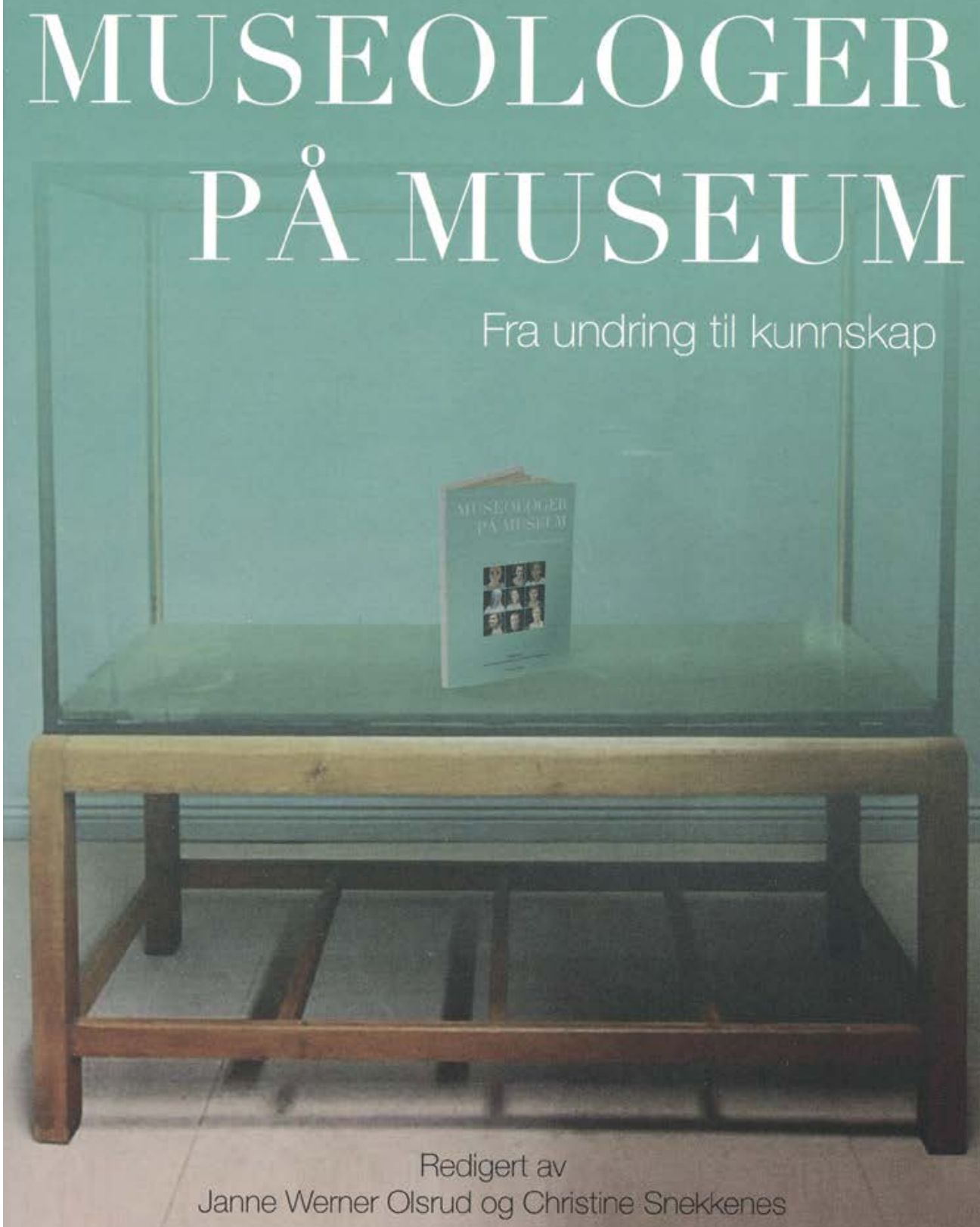

Fra undring til kunnskap

Novus forlag

Fig.1. This book written by former MA-students on the basis of their dissertations, shows a good cross section of topics researched by museology students at the University of Oslo. 
are metaphors that I find in the relevant whitepapers from the period. In 1975 a grant scheme for "half-public" museums became operative. The county authorities decided which museums could join the scheme and the amount of money due to each institution. The state was then obliged to refund a given percentage of the costs, differing from county to county. "The regime was characterised as a straw into the state treasury, and had far-reaching consequences for the Norwegian museum landscape", museum administrator Jon Birger has claimed (Østby 2009). And he continues: "The result was a formidable flourishing of new institutions and a strengthening of a decentralised museum structure" (Østby 2009). This financing scheme did not only effect an increase in the number of museums, but also made the institutions able to employ a large number of historians, art historians, ethnologists and folklorists in institutions that had earlier relied on volunteers. The museum sector was professionalised. Various measures were put in place to prevent an uncontrolled increase in budgets, but the main regime was in place well into the 1990s.

In 1996 a Norwegian Official Report of 291 pages was presented to the government (NOU 1996:7). This was the most extensive overview of the museum sector in Norway to date, and in many ways, it still is. The board that had been given the task to report on the condition of the museum sector proposed a long range of measures. Ideologically the most notable novelty was the use of the catchword "dialog institution". This concept was developed through a thorough discussion of what it means that the museum is an institution of the society. A special emphasis was given to the ecomuseum-movement, and a museum idea founded on local participation and what the museum can do for the populace. But this was also a critical assessment where the authors insisted on keeping two ideas upfront in museum work: The museum should be a meeting place and a repository for societal memory. This meant that all the basic functions of museums were pivotal: collecting, research, preservation and serving as a place for public dialog. What was also stressed was that museums of cultural history should be concerned with not only cultural but also ecological diversity. All together a long range of measures were discussed and proposed, considering financing, organisation, museum education, technological advancements and so forth, many of which laid the foundation of a new museum policy in the years to come.

The report attempted to make a concerted overview of what was named a "wild-growing flora", and "a decentralised multiplicity". For not only did the museum field include a wild variety of small cultural historical and open air museums, Norway also "lacked" national museums in the same sense as other nations, except for the National Gallery. University museums in the biggest towns were, and still are, responsible for all archaeology and natural history, and they are regional, not national museums. These museums are part of their respective universities, and hence governed by the Ministry of Education and Research (Maurstad \& Hauan 2012). The Ministry of Culture is today responsible for most of the existing museums, but there are also many museums which are owned and/or financed by other ministries. And last, but not least, the rest of the heritage sector is mainly a responsibility of the Ministry of Climate and Environment. In 1996 the Ministries had different names, but the governmental museum and heritage structures were then, as now, fragmented. 


\section{REFORMING THE FIELD}

The one way to reduce fragmentation that was eagerly seized upon was to merge museums. The museum field was changing already in 1996, and in the years to come "clearing the ground" seem to have become a political mantra. In the 1990s establishing a museum act was put on the agenda on several occasions, but the proposals were not developed. Today in 2018 there are signs that the question might yet again come on the agenda, following what has happened in other Nordic countries.

In the white paper, "St. meld 22 (19992000). Kjelder til kunnskap og oppleving" (Sources to knowledge and experience) a new vision of the museum field was outlined. Noticeably, the all encompassing overview and concerted treatment of the museum sector from the previous report was gone. Here only the museums that were subject to the Ministry of Culture were given notice, and further, these museums were treated in relation to Libraries and Archives. The ALMsector (ABM in Scandinavian) thus became a reality in Norway. The paper proposed to initiate a process "with the aim of clearing up in every district and region, to leave only a limited number (1-6) consolidated museums or museum networks in each county (St.meld. nr.22, 8)." Each museum unit should become economically and professionally strong and be part of a concerted national network of museums. The implementation of this process has been the hallmark of museum policy and museum work from the very local to national level in the years since. Even if this reform process is now officially over, the number of museums in Norway is still decreasing, as new units enter the consolidated museums. This is not the place to evaluate the reform, and so far there has been no comprehensive evaluation. Those that have looked at one or more of the new museum units or counties have identified problems, but have also seen positive results in the form of larger professional environments and more effective use of resources. What has also been pointed out is the degree to which the reform strengthened the structural means of government to lead a more concerted sector politics. In opposition to this, the 1996 board had proposed a more bottom up solution where the professional need would be the driving force and the structure developing accordingly. The "decentralised multiplicity" they had described was not an altogether negative term, by the end of the decade, it was seen as a reason to act.

Art museums have been among the most resistant in becoming part of larger museum units. And maybe the one spearhead that was launched early in the reform process, the new National Museum of Art, Architecture and Design, was a particularly unhappy case to go forward with. The merging of the National Gallery (established in 1837), the Museum of Decorative Arts and Design (established 1876), the Museum of Contemporary Art (established 1988) and the Museum of Architecture (established 1975) in 2003 was to become a long and conflictual process (see Sandberg 2008). Now a new gigantic museum building is about rising by the harbour in Oslo, where the museums will be truly consolidated under one roof in 2020. The building might have appeased the strongest objections, in the end. And if there is one common denominator in Norwegian museum world in the 2000s, it is the buildings. Enormous sums have been injected into the museum infrastructure in the form of storage facilities and "starchitecture". The reform brought new money, but so did also what was termed the cultural uplift, a political aim by the then ruling Social democratic government of using 1 percent of the BNP on cultural 
development. And museums, so it was claimed in 2013, were lifted the most (NOU 2013:4).

\section{"BREAK" AND THE BREAKING UP OF THE ABM SECTOR}

What were the museums to do with the new resources stemming from rationalizations and new funds, how were they to act as museums? The organisation Norwegian Museum Development was active in the 1990s, serving as an advisory board for the government with the responsibility of initiating projects in the museum sector. In 2003 it was merged to become part of the new institutions for Archives, Libraries and Museums, the ABMinstitution that would have a central role in also in effectuating policies in these sectors. It would also be the statistical office for the sector, run and finance strategical development projects, and thereby pointing out directions for libraries, archives and museums. A focal point was the development of the societal role of museums.

One such project was Brudd, in English Break, that had a vision of looking critically on museums and the society they served. Difficult matters and histories deserved and should be told by museums, and Brudd served as a common network for developing such projects. This was one of the longest living projects in $\mathrm{ABM}$ and did have a profound effect on how museums strived to include new voices, meet themes that were regarded as tabu, and to give museum workers a common platform to discuss and work from (see Brudd. Om det ubehagelige, tabubelagte, marginale, usynlige, kontroversielle, ABM-skrift 26).

In 2010 however, the ABM-utvikling was dismantled and from 2011 the duties concerning the museum sector were taken over by the Norwegian Art Council, still serving many of the same goals. From 2018 this museum section is once again on the move, as the Parliament has decided to move the whole section to the town of Bodø in the North of Norway. How this will inflict on the duties performed, the projects initiated etc. is still to be seen. But the bonds between the library, archives and museum sector are now definitely broken.

\section{NEW MUSEOLOGIES AND THE SOCIETAL ROLE}

As cultural historian Ole Marius Hylland has discussed, the "new" has been a hallmark of the international museology discourse the last decades. He points to concepts as rethinking, reshaping, reinventing, new museology, and the postmodern museum. This rhetoric, claims Hylland, was also included in the official museum policy. "The last twenty to thirty years ideas about change, watershed, and the new have paradoxically become among the most consistent parts of the museum discourse" (Hylland 2017:86). Museums in Norway, along with the museum authorities, are following the international trends in museum development. One of the interesting features might be that museological literature and strategies developed in other countries as responses to austerity measures, cut of funding or lack of legitimacy was translated into official politics in Norway. Reinvention has been as much an official statement as a call from the museum sector. This situation is complex and interesting, and the closer study of it would probably reveal more complex patterns. But there is an important irony in how museums merge, become more professional and efficient, remove themselves from some of the active volunteer groups, whilst at the same time striving to become inclusive and participatory through engagements with the publics drawn 
116 from international literature and examples (see for example Tveiten 2016).

The interesting question that the abovementioned Hylland raises, however, is what the societal role of the museum is adding up to. In his analyses the societal role of museums have been there since the infancy of the institutions, and new roles and responsibilities have constantly been added to, and only partly replacing, existing ones. This has led to a sedimentation where museums, "in addition to being scientific institutions have become identity institutions, recreational institutions, inclusive institutions, tourism institutions, dialog and debate institutions and digital institutions" (Hylland 2017:85). Why this development and why has it become so important to talk about the societal roles? The crisis of legitimation is one answer, and in our context, it might be fruitful to think about the museological discourse not only as an answer to the question of legitimacy, but also a driving factor that makes "The Relevant Museum" in to the norm.

\section{MUSEUM EDUCATION: WHICH FLOWERS TO WATER?}

The wild flora on the museum field has become a perspicuous and ordered herbarium. We know how many museums there are, what they do, how many objects they take care of, how many visitor they welcome. But who will they employ? As earlier stated, the consequence of the 1975 act was a professionalization of the museums. These employees are now going on pension, and it is still an open question who the museums are employing, which expertise they seek. In the 1996 report, museum education was on the agenda. Museum science and conservation were the two fields of knowledge that were considered, and the recommendation was to establish museumskunnskap (museum knowledge/science) as a one year subject in a University, before expanding the education further. The conservation studies that had been established at the University of Oslo were also heralded as a good beginning. But there were no concrete results of the interest in education that was promoted. One obvious reason for this is that the Universities and colleges do not establish educational programmes by decree from the government, but are institutions with academic freedom. However, there is a notable development from the wish to establish museumskunnskap in 1996 to the call for education in museum leadership in an evaluation of the museum reform in 2013. In this last evaluation the authors point to the need for education in museum leadership, as the large institutions which we now have, call for professional leaders (Fossestøl et al. 2013).

Museology is a minor player in this field, but a player which has been successful according to most criteria. This would have pleased the proponents of "new museology" in the 1990s. In Norway they fought a rather strong resistance when trying to convince museum employees and academics alike that an education in museology was needed, with John Aage Gjestrum as a leading proponent. The longer history of the fate of museology in Norway has been forcefully told by Gjestrum (see for example Gjestrum's articles in the Journal of Nordic Museology 1-2 2001). The resistance first and foremost came from those that claimed that there were no need for a new subject or discipline, rather short courses as additions to the old disciplinary educations would serve the need. Changes in the museum structure, changes in the international academic structure, and not least changes in the conception of what the primary tasks of museums are, have all but 
changed this negative attitude. Not only are there programmes in heritage and museum studies in several universities, but there has also been an increased interest for studying museums in disciplines that earlier would be reluctant in making museums an object of study. This means that historians, literary scholars, anthropologists, art historians, geographers, cultural historians have all paid increasing attention to the museum and heritage field.

The only MA-programme in museology in Norway is located at the University of Oslo, at the Department for Culture Studies and Oriental Languages, in close collaboration with culture history (formerly ethnology and folklore). The MA-programme started in 2010 and was reorganised into a MA-programme in Museology and Heritage Studies from 2015. This is a fulltime programme that welcomes students with a BA from disciplines in the human and social sciences, and it works as a two year intensive programme, where students are taught theories and histories of museums and heritage, but also with a strong emphasis on getting practical experience with museum work: A course in exhibition making and theory combines theories of materialities with setting up a full-scale exhibition in the Museum of Cultural History. There is also a three-month placement period and extensive use of museum and heritage institutions as partner in teaching courses. The first five years 35 students passed their MA exams, presently 38 students are enrolled in the programme (see Olsrud \& Snekkenes 2014, with articles written by MA-graduates). As a study programme it has proved successful, and so far, our students are welcomed by the museum and heritage sector. However, one main consideration for us in the programme is to develop further the contact zone with the sectors, and to establish more collaborative teaching and research. Through a five-year long funding period starting from 2019 we will develop this collaboration further in interdisciplinary program (HEI 2017). Today we have an associate professor in 20 percent position, Bjørn Sverre Hoel Haugen who has his daily work at one of the large consolidated museums, Anno museum in Hedemark county. We have a professor in 20 per cent position, Chris Whitehead, who has his daily work at Newcastle University. While museologist Marzia Varutti, cultural historian Line Esborg and the author of this text run the program on daily basis.

Museology and heritage studies are gaining steadily more ground in Norway as internationally. In our Cultural History and Museology group in Oslo museums have been an important research topic for scholars who view themselves as cultural historians and museologists alike. People have written on and worked on large research projects on international and Norwegian museum history (Arne Bugge Amundsen, Anne Eriksen, Line Esborg, Bjarne Rogan), on natural history museums (Brita Brenna, Liv Emma Thorsen), on diversity, indigeneity and museums (Saphinaz Naguib, Marzia Varutti). Postdocs write on exhibition and Kunstkammer history (Mattias Bäckström, Mattias Ekman), and presently a number of PhD's working on a range of museum fields.

However we are not the only ones educating students for the heritage and museum sector, most Norwegian universities do in some way or another. To name but a few: In Trondheim they have a BA and MA in Cultural Heritage, where a broad range of topics are taught. In Bergen they have museology and heritage as part of BA and MA in Cultural Studies. They have also opened 15 ECT courses for museum employees, 
118 with the title "To research on and in museums" thereby offering a much sought for possibility for museum employees to get a more substantial training in museum research and museology.

\section{RESEARCH IN AND ON MUSEUMS}

Research in museums has been high up on the agenda in reports and policy documents at least since the 1996-report mentioned earlier, but it seems that the full fruit of this work has only started to become visible during the last few years. ABM-utvikling initiated a $\mathrm{PhD}$ school in collaboration with the University of Bergen in 2000 (Johansen 2000). A research program where museum employees could apply for money for research projects was set up in 2009 (FoMA). And from 2011 museums had to report not only on collection, conservation and exhibition work, they would also report on research activities and were asked to provide research strategies. The Norwegian Museum Association, celebrating its 100th anniversary this year, has been an eager strategist in developing research in museums and have succeeded in establishing a new peer reviewed journal, Norsk museumstidsskrift, and also in making museums part of the official research output register, Cristin. Putting research on the agenda is thus not so much a governmental prescription as a vision for how museums might develop in the future. In this picture museology has a part, but research in and on museums will develop in different fields and disciplines also in the future, and this we can only welcome.

\section{LITERATURE}

Brudd. Om det ubehagelige, tabubelagte, marginale, usynlige, kontroversielle, ABM-skrift 26.

Eriksen, Anne 2013. "Utviklingen på museumsfeltet."

Delrapport til Kulturutredningen 2014 (NOU 2013:3).
Fossestøl, Knut, Eric Breit \& Hanne Heen 2013.

Organisering av museene. En evaluering

av organisasjonsformer $i$ kjølvannet av museumsreformen. Oslo: Kulturrådet.

Hylland, Ole Marius 2017. "Museenes samfunnsrolle:

Et kritisk perspektiv." Norsk museumstidsskrift.

3:2, 77-91.

Johansen, Anders 2000. "Museumsforskning som museumsutvikling." Nordisk museologi 2, 59-68.

NOU 2013:4.

Kulturutredningen 2014. Oslo.

Maurstad, Anita \& Marit Anne Hauan (eds.) 2012.

Museologi på norsk. Trondheim: Akademika.

NOU 1996:7. Museum. Mangfald, minne, møtestad. Oslo.

Olsrud, Janne Werner \& Christine Snekkenes (eds)

2014. Museologer på museum: Fra undring til

kunnskap. Oslo: Novus.

Sandberg, Lotte 2008. Alle snakker om museet. Oslo: Pax.

St.meld.nr.22 (1999-2000) Kjelder til kunnskap og oppleving. Oslo: Departementet.

St.meld.nr.49 (2008-2009) Framtidas museum.

Forvaltning, forskning, formidling, fornying. Oslo:

Departementet.

Tveiten, Sigrid Roholdt 2016. Frivillighet etter museumsreformen: Profesjonalisering og deltakelse. Master thesis University of Oslo.

Østby, Jon Birger. 2009. "Museene og myndighetene:

Hovedtrekk i museumspolitikken fra Hoveutvalget til museumsreformen." In "En Smuk Fremtid" Trøndelag Folkemuseum Sverresborg 100 år. Trondheim: Tapir Akademiske Forlag, 163-168.

Brita Brenna, Professor of Museology

b.s.brenna@ikos.uio.no

Centre for Museum Studies

IKOS

University of Oslo

Box 1010 Blindern

N-0315 Oslo, Norway 